\title{
Characterization of ginger proteases and their potential as a rennin replacement
}

\author{
Hou-Pin Su, ${ }^{a}$ Mei-Ju Huang ${ }^{a}$ and Han-Tsung Wang ${ }^{b *}$
}

\begin{abstract}
BACKGROUND: Ginger rhizome (Zingiber officinale Roscoe) contains ginger proteases and has proteolytic activity. Ginger proteases have been used for tenderizing meat but rarely for milk clotting. The purpose of this study was to purify ginger proteases and to research their biochemical characteristics.

RESULTS: The milk clotting activity (MCA) and proteolytic activity (PA) of the proteases was stable after storage at $4{ }^{\circ} \mathrm{C}$ for $24 \mathrm{~h}$. The MCA and PA of fresh ginger juice with $0.2 \%$ L-ascorbic acid remained stable for 6 days at $4{ }^{\circ} \mathrm{C}$. When under storage at $-80{ }^{\circ} \mathrm{C}$ for 2 months, the MCA and PA of the fresh ginger juice and acetone precipitate were still high. Two peaks with protease activity were purified from a DEAE FF ion-exchange column; the specific activity (units $\mathrm{mg}^{-1}$ protein) of the MCA (MCSA) and PA (PSA) for the first peak was significantly higher than the second peak $(P<0.05)$. The protease activity of the ginger proteases was significantly inhibited by E-64, leupeptin, and iodoacetic acid. Zymography results showed that two protease fractions purified from ginger juice with 62 and 82 kDa had a higher PA against $\alpha$-and $\beta$-casein than against $\kappa$-casein.

CONCLUSION: The ascorbic acid addition significantly stabilized the MCA and PA of ginger proteases. The protease inhibition test suggested that ginger proteases belonged to the cysteine type. The biochemical characteristics of ginger protease described in this paper can provide useful information for making new milk curd products.

(c) 2009 Society of Chemical Industry
\end{abstract}

Keywords: ginger proteases; L-ascorbic acid; milk clotting activity; proteolytic activity

\section{INTRODUCTION}

Ginger rhizomes (Zingiber officinale Roscoe) are grown in tropical Asia and can be found in Southeast Asia, India, Africa, and the West Indies as well. Ginger has often been used as a peptic drug and in other drugs in Chinese medicine from ancient times, ${ }^{1}$ and applied as a meat tenderization agent. ${ }^{2}$ Ginger rhizomes contain ginger proteases, which are separated into two fractions (GPI and GP II) by a DEAE-cellulose column, with a molecular mass of about $22.5 \mathrm{kDa}^{3}$ The complete amino acid sequence for GP II contains 221 amino acids, while about $98 \%$ of the amino acid sequence for GP I has been determined. ${ }^{1}$ GP II is a cysteine protease ${ }^{4}$ with two predicted glycosylation sites at Asn 99 and Asn 156. ${ }^{1}$ The ginger proteases are separated into three fractions by isoelectric focusing with $\mathrm{p} /$ values of $4.5,4.6$, and 4.8 , respectively. All the proteases had a molecular mass of about $29000 .^{5}$

Together, the protease activity of ginger proteases has $\mathrm{pH}$ optima between 5.0 and 5.6, but separately the protease activity of GP I and GP II has a pH optimum of 6.5-7.0. ${ }^{2,3}$ Ginger proteases extracted from ginger acetone powder have their peak protease activity at $60^{\circ} \mathrm{C}$ and rapidly denature at $70^{\circ} \mathrm{C} .{ }^{2,6}$ Adding sodium ascorbate has the benefit of keeping ginger protease activity between 5 and $50{ }^{\circ} \mathrm{C}$ and adding $\mathrm{Ca}^{2+}$ increases the activity, but $\mathrm{Cu}^{2+}, \mathrm{Hg}^{2+}, \mathrm{Cd}^{2+}$, and $\mathrm{Zn}^{2+}$ all have negative effects. ${ }^{5,6}$ The milkclotting activity of ginger protease is significantly improved by $\mathrm{Mg}^{2+}, \mathrm{Ca}^{2+}$, and $\mathrm{Fe}^{2+}$. The coagulation of milk is a fundamental process in cheese making, and coagulating enzymes have been utilized for centuries in cheese manufacturing. Traditionally, enzyme coagulants such as rennin are derived from animal sources, principally calf rennet. ${ }^{8}$ However, the combination of an increase in cheese consumption and mad cow disease has created a rennet shortage, and in response substitute milk-clotting enzymes from other animals, plants, and microbial sources have been developed together with biotechnology-derived coagulants. ${ }^{9}$ Ideally, a rennin replacement should be an acid protease with a similar cutting site of chymosin to casein as well as a suitable milk-clotting/total proteolytic activity ratio. ${ }^{10}$ There have been many studies on milkclotting activity of plant source protease. ${ }^{9,11,12}$ However, there is little literature available on milk-clotting activity of ginger protease.

Ginger milk curd is a kind of snack in the south China area, produced by mixing the hot fresh ginger juice with milk to form a tofu pudding-like sweet snack. The milk-clotting activity of ginger protease is a key point in making this delicious snack. In the past, studies were focused on the protease activity of ginger proteases. This paper examines the biochemical characteristics and milkclotting activity of ginger proteases. This research can provide useful information for making milk curd products with ginger and increase the diversity and additional value of milk products.

\footnotetext{
Correspondence to: Han-Tsung Wang, Department of Animal Science, Chinese Culture University, No. 55, Hwa-Kang Road., Yang-Ming Shan, Taipei, Taiwan 111,ROC.E-mail:rumen@seed.net.tw
}

a Department of Animal Science and Technology, National Taiwan University, Taipei, Taiwan 106, ROC

b Department of Animal Science, Chinese Culture University, Yang-Ming Shan, Taipei, Taiwan 111, ROC 


\section{MATERIALS AND METHODS}

Preparation of crude ginger proteases and partial purification process

Crude ginger proteases were prepared using a modification of the procedure developed by Thompson et al. ${ }^{2}$ Ginger rhizomes were washed, cut into small pieces, and homogenized using a blender. The juice was filtered to separate out residual solids and divided into two parts: one part with $2 \mathrm{mg} \mathrm{mL}^{-1}$ L-ascorbic acid (Sigma-Aldrich, Inc., St Louis, MO, USA) added and the other without. The ginger juice was spun in a centrifuge at $9000 \times g$ for $30 \mathrm{~min}$ at $4{ }^{\circ} \mathrm{C}$ (Kubota KR-2000T, Double Eagle Enterprise Co., Ltd, Taipei, Taiwan) to collect the supernatant of the fresh ginger juice. The supernatant was stored in ice; three parts (w/v) of cold acetone (Echo Chemical Co., Ltd, Miaoli, Taiwan) were then slowly added. The solution was stirred for $10 \mathrm{~min}$ and precipitated to obtain acetone precipitate by centrifugation at $9000 \times \mathrm{g}$ for $15 \mathrm{~min}$ at $4{ }^{\circ} \mathrm{C}$; the supernatant was then removed. Ginger proteases were purified using the procedure developed by Ohtsuki et al. ${ }^{5}$ with some modifications. The acetone precipitate was dissolved in a $0.05 \mathrm{~mol} \mathrm{~L}^{-1}$ MES buffer solution ( $\left.\mathrm{pH} 6.0\right)$ and applied to a Hi-Trap DEAE FF column (GE Healthcare Bio-Sciences $A B$, Uppsala, Sweden). The elution was washed with $20 \mathrm{mmol} \mathrm{L}^{-1}$ sodium phosphate buffer $(\mathrm{pH}$ 7.0) and eluted with a linear gradient of $20 \mathrm{mmol} \mathrm{L}^{-1}$ sodium phosphate buffer $(\mathrm{pH} 7.0)$ with $1 \mathrm{~mol} \mathrm{~L}^{-1} \mathrm{NaCl}$. The column was monitored at $280 \mathrm{~nm}$ to detect proteins, and protein fractions were concentrated and desalted for enzyme assay. The protein concentration of collected samples was measured using Bradford's procedure ${ }^{13}$ with Coomassie blue dye (Bio-Rad Laboratories, Hercules, CA, USA). A bovine serum albumin solution was used to establish a standard curve for measuring the protein concentration.

\section{Milk-clotting activity assay}

Milk-clotting activity (MCA) was measured through a modification of Sousa and Malcata's procedure. ${ }^{14}$ The milk substrate was prepared by dissolving $12 \mathrm{~g}$ skim milk powder in $100 \mathrm{~mL} \mathrm{CaCl}$ solution $\left(0.01 \mathrm{~mol} \mathrm{~L}^{-1}\right) .2 \mathrm{~mL}$ of milk substrate was heated at 37 and $60{ }^{\circ} \mathrm{C}$, and then mixed with $0.2 \mathrm{~mL}$ of the enzyme solution. The time for the formation of fragments was measured with a stopwatch. One unit of milk-clotting activity was defined as follows:

$$
M C A=2400 / t \times F
$$

where $t$ is the time for the formation of fragments (s), and $F$ is the dilution coefficient.

\section{Proteolytic activity assay}

The proteolytic activity (PA) was measured using the procedure developed by Brock et al. ${ }^{15}$ An azocasein substrate solution (1\%) was prepared by dissolving $10 \mathrm{mg}$ azocasein (Sigma-Aldrich) in $1 \mathrm{~mL}$ of $100 \mathrm{mmol} \mathrm{L}^{-1}$ MES buffer ( $\mathrm{pH} \mathrm{6.0).} \mathrm{A} 0.2 \mathrm{~mL}$ substrate solution was placed into a $1.5 \mathrm{~mL}$ microcentrifuge tube by pipette and $0.2 \mathrm{~mL}$ protease sample solution was added. The mixture was incubated at 37 and $60^{\circ} \mathrm{C}$ for $20 \mathrm{~min}$ and the assay was terminated through the addition of $0.2 \mathrm{~mL}$ of $1.5 \mathrm{~mol} \mathrm{~L}^{-1} \mathrm{HClO}_{4}$. The contents were mixed thoroughly and stored in ice for $1 \mathrm{~h}$ to allow complete precipitation of the remaining azocasein. The samples were put through the centrifuge at $15000 \times g$ for 10 min; $0.1 \mathrm{~mL}$ of the supernatant fluid was transferred to a microplate and an equal volume of $1 \mathrm{~mol} \mathrm{~L}^{-1} \mathrm{NaOH}$ was added. Absorbance was determined at $450 \mathrm{~nm}$ using a microplate reader (Model
Table 1. Protease inhibitors used in protease propriety test and effect on protease activity of ginger protease

\begin{tabular}{|c|c|c|}
\hline Inhibitor & Target protease & $\begin{array}{c}\text { Working } \\
\text { concentration }\end{array}$ \\
\hline AEBSF $^{a}$ & Serine protease & $1 \mathrm{mmol} \mathrm{L}^{-1}$ \\
\hline$E-64^{b}$ & Cysteine protease & $10 \mu \mathrm{mol} \mathrm{L}-1$ \\
\hline Leupeptin & Cysteine protease, serine protease & $100 \mu \mathrm{mol} \mathrm{L}^{-1}$ \\
\hline lodoacetic acid & Cysteine protease & $1 \mathrm{mmol} \mathrm{L}-1$ \\
\hline EDTA $^{c}$ & Metalloprotease & $1 \mathrm{mmol} \mathrm{L}^{-1}$ \\
\hline Pepstain A & Aspartic acid protease & $1.5 \mu \mathrm{mol} \mathrm{L} \mathrm{L}^{-1}$ \\
\hline
\end{tabular}

550, Bio-Rad Laboratories). One unit was defined as $1 \mathrm{mg}$ azo group released per minute. Different concentrations of azocasein solutions were used to plot a standard curve for measuring the proteolytic activity. The $K_{\mathrm{m}}$ and $V_{\max }$ values for protease of fresh ginger juice were determined by using this method under $\mathrm{pH} 6$ at $60^{\circ} \mathrm{C}$.

\section{Protease inhibitor test}

The protease inhibitor test used to measure the ginger proteases was a modification of the procedure developed by Ohtsuki et al. and Wang. ${ }^{5,16}$ For each assay tube, $0.18 \mathrm{~mL}$ of enzyme solution (dissolved in $50 \mathrm{mmol} \mathrm{L}^{-1}$ MES buffer, $\mathrm{pH}$ 6.0) was mixed with $0.02 \mathrm{~mL}$ of protein inhibitor solution (Sigma-Aldrich) at $15^{\circ} \mathrm{C}$ (Table 1). After $10 \mathrm{~min}$, the solution was mixed with $0.2 \mathrm{~mL}$ azocasein $\left(10 \mathrm{mg} \mathrm{mL}^{-1}\right)$ at $60^{\circ} \mathrm{C}$ for $20 \mathrm{~min}$. The residual enzyme activity was determined as in the previous step. The inhibition of protease activity was calculated from the difference between the inhibitor's untreated and treated samples.

\section{Protease storage stability test}

This study tested the storage stability of fresh ginger juice. Test samples with and without the $0.2 \%$ L-ascorbic acid were separated equally into two parts that were then stored at 4 or $-80^{\circ} \mathrm{C}$. The proteolytic and milk-clotting activity of the storage test samples were determined after different storage periods as previously described.

\section{Electrophoresis and Zymography}

Sodium dodecyl sulfate-polyacrylamide gel electrophoresis (SDSPAGE) was performed as described by García-Carreño et al. ${ }^{17}$ using $12.5 \%$ polyacrylamide gels and a molecular weight protein standards marker (Bioman Scientific Co., Ltd, Taipei County, Taiwan). After electrophoresis, gels were stained using RAPIDStain ${ }^{\mathrm{TM}}$ (Bioman Scientific Co., Ltd, Taipei County, Taiwan) to identify the protein bend. Zymography was performed as described by García-Carreño et al. ${ }^{17}$ The ginger protease prepared from acetone precipitation was separated by $12.5 \%$ native polyacrylamide gels containing $1 \% \alpha-$, $\beta$-, or $\kappa^{- \text {casein }^{17}}$ (Sigma-Aldrich). The native PAGE standard protein kit from Sigma-Aldrich on zymography was used in native PAGE (proteins in kit: lactoalbumin, $14.2 \mathrm{kDa}$; albumin from chicken egg white, $45 \mathrm{kDa}$; albumin from bovine serum, $66 \mathrm{kDa}$ monomer and $132 \mathrm{kDa}$ dimer). After electrophoresis, gels were incubated in $50 \mathrm{mmol} \mathrm{L}^{-1}$ MES buffer $(\mathrm{pH} 6.0)$ for $35 \mathrm{~min}$ at $37^{\circ} \mathrm{C}$. The gels were stained with RAPIDStain ${ }^{\mathrm{TM}}$, then destained in 
distilled water until a clear zone appeared. The clear zones in the gels indicated proteolytic activity.

\section{Statistics}

The experiment design for this study was a two-factor nested design. ${ }^{18}$ Data were analyzed for the variance of the nested design by a statistical analysis system (SAS 8.2, SAS Institute, Cary, NC, USA).

The mathematical model of the two-factor nested design was as follows:

$$
X_{i j k}=\mu+\alpha_{i}+\beta_{(i) j}+\varepsilon_{(i j) k}
$$

where $i=1,2$ (the obtained way of the ginger protease of acetone precipitate, with or without L-ascorbic acid), $(i) j=1,2$ (the collected fraction of the ginger proteases of acetone precipitate during purification), and $k=1,2,3,4$ (repeat, $n=4$ ).

The data are presented as mean values \pm standard deviations. Data were analyzed through variance and Duncan's new range test using a statistical analysis system (SAS 8.2, SAS Institute).

\section{RESULTS AND DISCUSSION}

\section{Stabilization of ginger protease during storage}

PA and MCA of fresh ginger juice gradually decreased after storage at $4{ }^{\circ} \mathrm{C}$ for $24 \mathrm{~h}$ (Figs 1 and 2). After 6 days storage at $4{ }^{\circ} \mathrm{C}$, the fresh ginger juice with $2 \mathrm{mg} \mathrm{mL}^{-1} \mathrm{~L}$-ascorbic acid addition had a residual MCA and PA of over $90 \%$ (Figs 1 and 2). Samples without L-ascorbic acid had only about $10 \%$ residual MCA and PA and the ginger juice had turned the color brown. A previous study of ginger proteases indicated that after storage at $5{ }^{\circ} \mathrm{C}$ for 4 days the residual proteolytic activity of fresh ginger juice decreased to $20 \%$, while samples with $0.2 \%$ sodium ascorbate added had residual proteolytic activity of about $87 \%$ after 14 days storage at $5^{\circ} \mathrm{C}^{6}$ The fresh ginger juice could maintain full MCA and PA when stored at $-80^{\circ} \mathrm{C}$ for more than 2 months (Table 2); L-ascorbic acid addition had no effect on activity maintenance for frozen storage in this study. The protease activity change shown in Fig. 2 indicated that fresh ginger juice might contain more than one kind of protease,

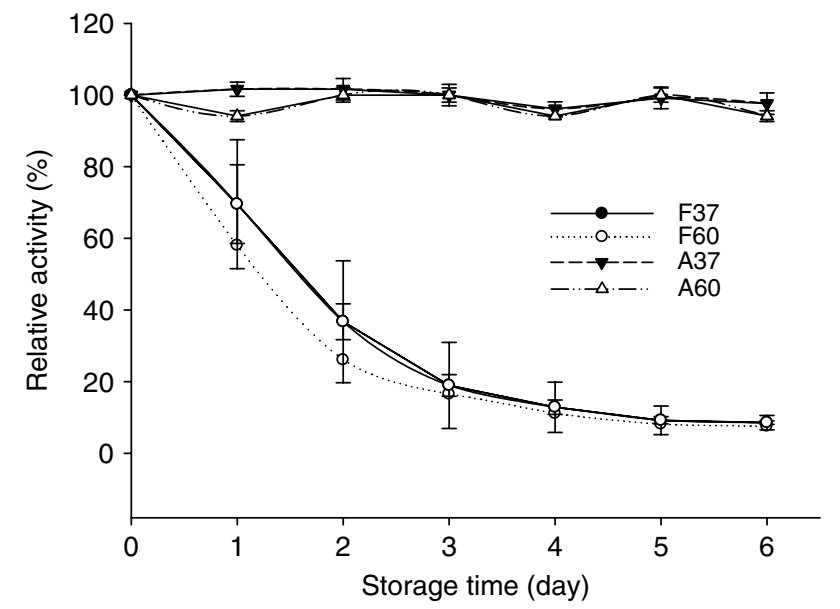

Figure 1. The storage stability of ginger juice milk-clotting activity at $4{ }^{\circ} \mathrm{C}$. (Mean $\pm \mathrm{SD}, n=4$ ). F37, ginger juice without ascorbic acid, tested at $37^{\circ} \mathrm{C} ; \mathrm{F} 60$, ginger juice without ascorbic acid, tested at $60^{\circ} \mathrm{C} ; \mathrm{A} 37$, ginger juice with $2 \mathrm{mg} \mathrm{mL}^{-1}$ ascorbic acid, tested at $37^{\circ} \mathrm{C}$; $\mathrm{A60}$, ginger juice with $2 \mathrm{mg} \mathrm{mL}^{-1}$ ascorbic acid, tested at $60^{\circ} \mathrm{C}$.

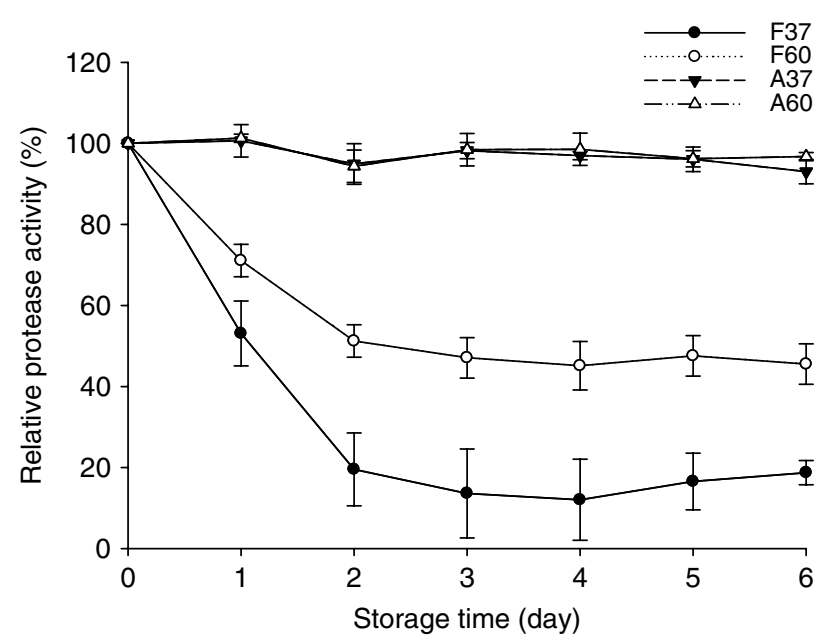

Figure 2. The storage stability of ginger juice protease activity at $4{ }^{\circ} \mathrm{C}$. (Mean $\pm \mathrm{SD}, n=4$ ). F37, ginger juice without ascorbic acid, tested at $37^{\circ} \mathrm{C}$; F60, ginger juice without ascorbic acid, tested at $60^{\circ} \mathrm{C} ; \mathrm{A} 37$, ginger juice with $2 \mathrm{mg} \mathrm{mL}^{-1}$ ascorbic acid, tested at $37^{\circ} \mathrm{C} ; \mathrm{A} 60$, ginger juice with $2 \mathrm{mg} \mathrm{mL}^{-1}$ ascorbic acid, tested at $60^{\circ} \mathrm{C}$.

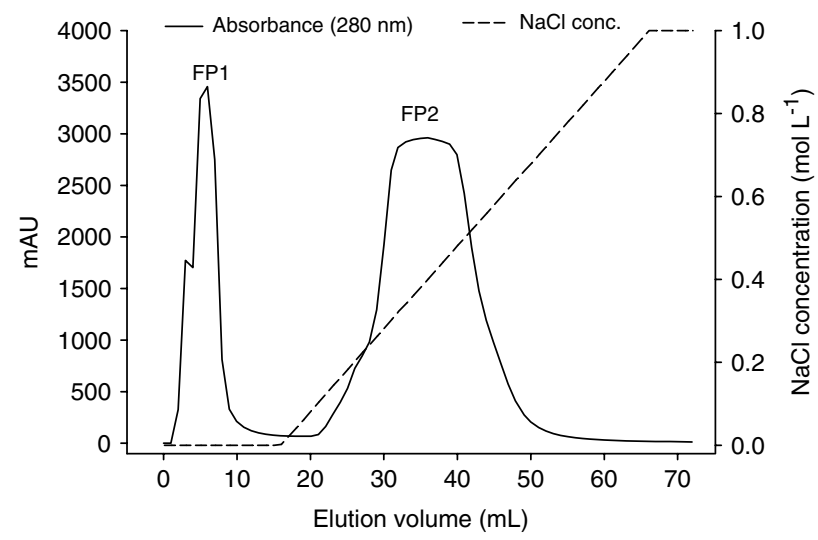

Figure 3. Hi-Trap DEAE FF ion-exchange chromatography of acetone powder from fresh ginger juice in sodium phosphate buffer $(\mathrm{pH} 7.0)$. FP1, fresh ginger juice fraction peak 1(wash step); FP2, fresh ginger juice fraction peak 2 (elution step).

as the protease with high thermal stability seems to have slightly decreased proteolytic activity when stored at $4{ }^{\circ} \mathrm{C}$ (F60 versus F37 in Fig. 2).

The brown color that appeared and the decrease in enzyme activity for the ginger juice may have been due to sulfhydryl group oxidation. Almost all higher plants contain polyphenol oxidase. ${ }^{19,20}$ Phenolic compounds are catalyzed by polyphenol oxidase to form o-quinones, ${ }^{21,22}$ which react with amino and sulfhydryl groups to form the colored product. ${ }^{21,23,24}$ Ginger proteases belonged to the cysteine type, and the sulfhydryl group in the activity site for cysteine proteases react with o-quinones or sulfhydryl groups through oxidation to form disulfide bonds. ${ }^{24,25}$ Because the sulfhydryl group reacted with o-quinones and oxidized to form a disulfide bond, the enzyme activity of ginger proteases was inhibited. The MCA and PA of fresh ginger juice decreased during storage time because the ginger proteases it contained were inhibited. Adding L-ascorbic acid can inhibit the reaction of polyphenol oxidase and reduce the $o$-quinones, so it prevents the ginger juice from browning and protects the enzyme activity of the 


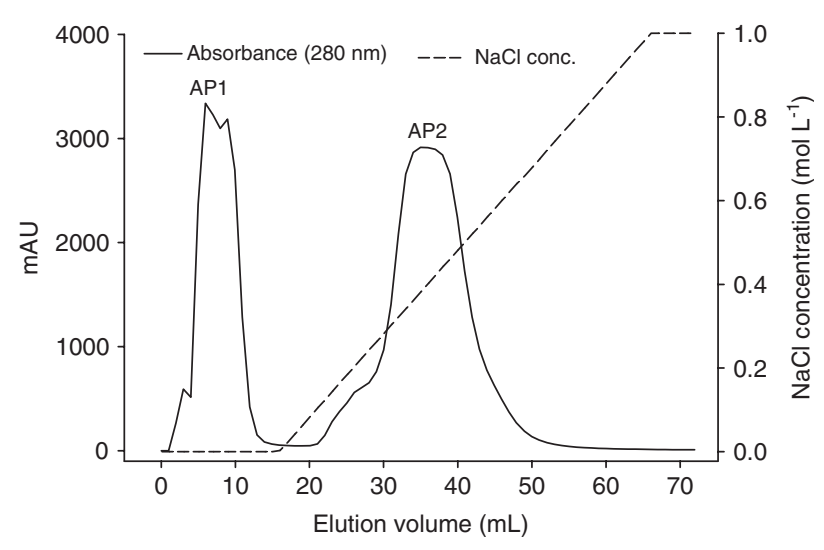

Figure 4. Hi-Trap DEAE FF ion-exchange chromatography of the acetone powder from fresh ginger juice with $0.2 \%$ L-ascorbic acid in sodium phosphate buffer ( $\mathrm{pH}$ 7.0). AP1, ginger juice with L-ascorbic acid fraction peak 1 (wash step); AP2, ginger juice with L-ascorbic acid fraction peak 2 (elution step).

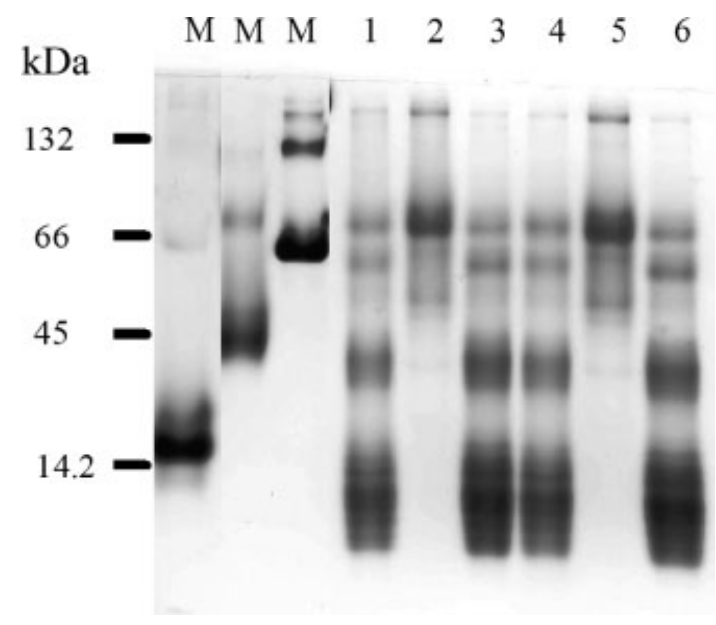

Figure 5. Native PAGE of ginger proteases. $M$, molecular weight marker; 1 , F; 2, FP1; 3, FP2; 4, A; 5, AP1; 6, AP2. Abbreviations are as Table 5.

ginger proteases. This suggests that an antioxidant addition was necessary to maintain fresh ginger juice protease activity under normal operating conditions and for non-frozen storage.

\section{Partial purification of ginger proteases}

Ginger juice acetone precipitate powder with and without L-ascorbic acid addition was applied to the DEAE FF ion-exchange chromatography column. After the purification process, two fractions with protease activity ( $\mathrm{P} 1$ and $\mathrm{P} 2$ ) were collected. The acetone precipitate from fresh ginger juice was designated as FP1 and FP2 (Fig. 3). The precipitate from the fresh ginger juice with $0.2 \%$ L-ascorbic acid added was designated AP1 and AP2 (Fig. 4). The protease purity of FP1 was 4.4 times higher than that of fresh ginger juice and the yield of FP1 was $20.8 \%$, but protease activity was only 0.8 times that of fresh ginger juice in FP2. The protease purity of AP1 was 2.9 times that of fresh ginger juice with $0.2 \%$ L-ascorbic acid and the yield of AP1 was $11.2 \%$, but AP2 only had half the protease activity compared to the fresh ginger juice with $0.2 \%$ L-ascorbic acid (Table 3 ). These results suggest that the major ginger protease was present in the washed-out fraction during the DEAE column purification process, and only a (a)

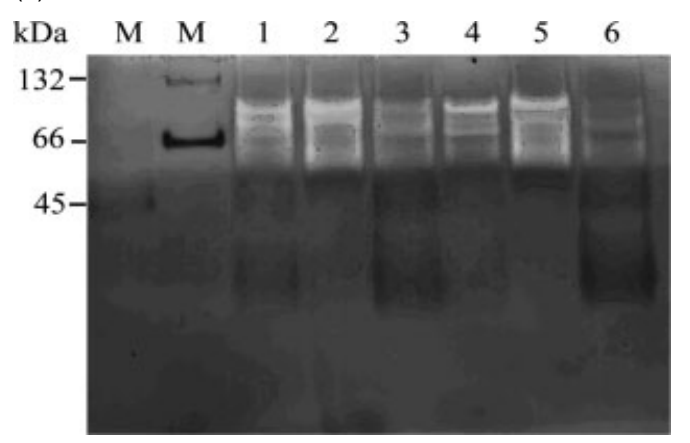

(b)

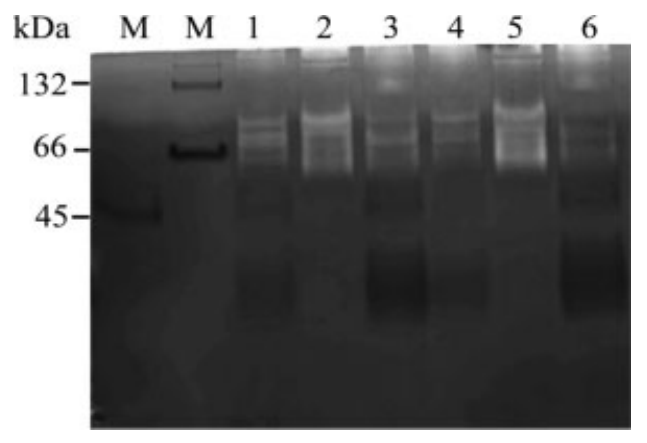

(c)

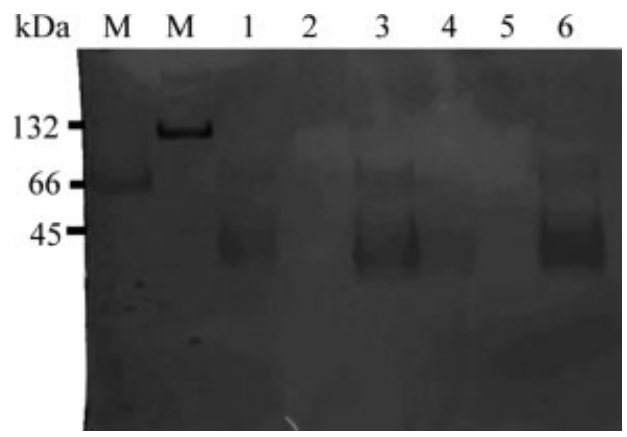

Figure 6. Zymography of ginger proteases. (a) Substrate: $\alpha$-casein; time: $35 \mathrm{~min}$. (b) Substrate: $\beta$-casein; time: $35 \mathrm{~min}$. (c) Substrate: $\kappa$-casein; time: 35 min. 1, F; 2, FP1; 3, FP2; 4, A; 5, AP1; 6, AP2. Abbreviations as in Table 5.

small amount of protease existed in the salt-eluted fraction. The $\mathrm{pl}$ range of the ginger protease was previously reported as 4.5-4.8, and two kinds of protease were separated by the DEAE cellulose and DEAE sepharose columns. ${ }^{3,5}$ The protease of ginger juice was eluted in a different pattern compared to previous studies. Studies of ginger protease purification indicated that protease activity was eluted at low $\left(0.1-0.2 \mathrm{~mol} \mathrm{~L}^{-1}\right)$ concentration of $\mathrm{NaCl}$ by the stepwise elution method. ${ }^{5,6}$ In this study, owing to maintain higher milk-clotting activity, the crude extract samples were filtered then applied to the Fast Protein Liquid Chromatography (FPLC) system without dialysis. If the crude extract sample of ginger juice contains higher salt or higher ionic strength during the extraction step, it may affect the elution performance.

\section{The enzyme activity and clotting activity of purified ginger proteases}

Previous studies indicated that the optimal $\mathrm{pH}$ for both ginger proteolytic and milk-clotting activity was $\mathrm{pH} 5$ or 6 , but milk-clotting activity remains stable under $\mathrm{pH} 6-9 .^{7}$ The highest proteolytic and 


\begin{tabular}{|c|c|c|c|c|}
\hline Time (days) & F37 & F60 & A37 & A60 \\
\hline \multicolumn{5}{|c|}{ Relative activity of the milk clotting activity (\%) } \\
\hline 0 & $100.0 \pm 0.0$ & $100.0 \pm 0.0$ & $100.0 \pm 0.0$ & $100.0 \pm 0.0$ \\
\hline 7 & $99.3 \pm 2.3$ & $102.2 \pm 9.4$ & $98.8 \pm 3.8$ & $99.4 \pm 1.1$ \\
\hline 14 & $98.3 \pm 1.7$ & $95.5 \pm 7.8$ & $97.7 \pm 2.0$ & $100.0 \pm 0.0$ \\
\hline 21 & $99.7 \pm 0.5$ & $93.5 \pm 7.0$ & $102.2 \pm 3.8$ & $96.8 \pm 4.0$ \\
\hline 28 & $102.7 \pm 9.2$ & $102.1 \pm 9.3$ & $99.8 \pm 3.2$ & $101.0 \pm 9.2$ \\
\hline 70 & $102.7 \pm 10.8$ & $101.6 \pm 2.8$ & $103.9 \pm 3.4$ & $105.2 \pm 9.0$ \\
\hline \multicolumn{5}{|c|}{ Relative activity of the proteolytic activity (\%) } \\
\hline 0 & $100.0 \pm 0.0$ & $100.0 \pm 0.0$ & $100.0 \pm 0.0$ & $100.0 \pm 0.0$ \\
\hline 7 & $90.3 \pm 14.0$ & $88.8 \pm 13.3$ & $90.2 \pm 9.1$ & $91.5 \pm 9.5$ \\
\hline 14 & $98.6 \pm 7.9$ & $96.9 \pm 6.7$ & $98.0 \pm 4.4$ & $98.5 \pm 4.4$ \\
\hline 21 & $92.2 \pm 12.6$ & $90.2 \pm 8.2$ & $96.9 \pm 5.7$ & $94.6 \pm 6.7$ \\
\hline 28 & $98.5 \pm 8.6$ & $95.7 \pm 4.6$ & $99.7 \pm 4.7$ & $102.3 \pm 1.4$ \\
\hline 70 & $98.5 \pm 3.4$ & $97.4 \pm 0.5$ & $96.8 \pm 3.1$ & $97.5 \pm 2.9$ \\
\hline \multicolumn{5}{|c|}{$\begin{array}{l}\mathrm{F} 37 \text {, ginger juice without ascorbic acid, tested at } 37^{\circ} \mathrm{C} ; \mathrm{F} 60 \text {, ginger juice } \\
\text { without ascorbic acid, tested at } 60^{\circ} \mathrm{C} ; \mathrm{A} 37 \text {, ginger juice with } 2 \mathrm{mg} \mathrm{mL}^{-1} \\
\text { ascorbic acid, tested at } 37^{\circ} \mathrm{C} ; \mathrm{A} 60 \text {, ginger juice with } 0.2 \% \text { ascorbic acid, } \\
\text { tested at } 60^{\circ} \mathrm{C} \text { (means } \pm S D, n=4 \text { ). }\end{array}$} \\
\hline
\end{tabular}

(a)

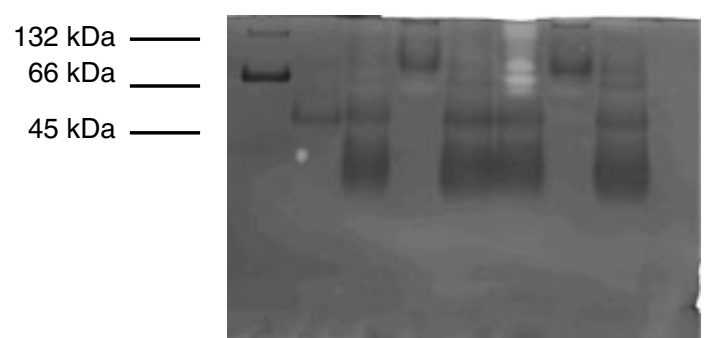

(b)

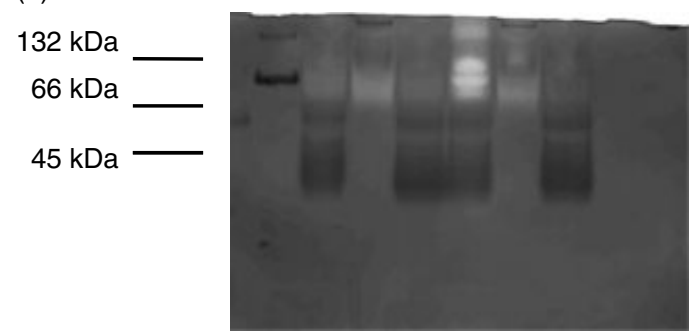

Figure 7. Zymogram of native PAGE with $\kappa$-casein as substrate. (a) Reaction time: 25 min. (b) Reaction time: 60 min. 1, F; 2, FP1; 3, FP2; 4, A; 5, AP1; 6, AP2. Abbreviations as in Table 5.

milk-clotting activity both reached a maximum at $60^{\circ} \mathrm{C} .^{7}$ According to the optimal enzyme activity condition, the purified ginger protease activity in this study was tested under $\mathrm{pH} 6$ at $60^{\circ} \mathrm{C}$. In this study, the $K_{\mathrm{m}}$ and $V_{\max }$ of crude extract fresh ginger protease determined by Lineweaver-Burk graphics before purification were $0.324 \mathrm{mmol} \mathrm{L}^{-1}$ and $80.4 \mu \mathrm{g} \mathrm{mL}^{-1} \mathrm{~min}^{-1}$, respectively. The effect of six protease inhibitor tests on the proteolytic activity of purified ginger proteases are shown in Table 4. The protease activity of FP1, AP1, FP2, and AP2 were significantly inhibited by adding E-64, leupeptin, and especially iodoacetic acid $(P<0.05)$. E-64 has a high specificity to cysteine proteases. ${ }^{26}$ The active-site thiolate of cysteine proteases attacks E-64 at C-3 of the oxirane ring, and

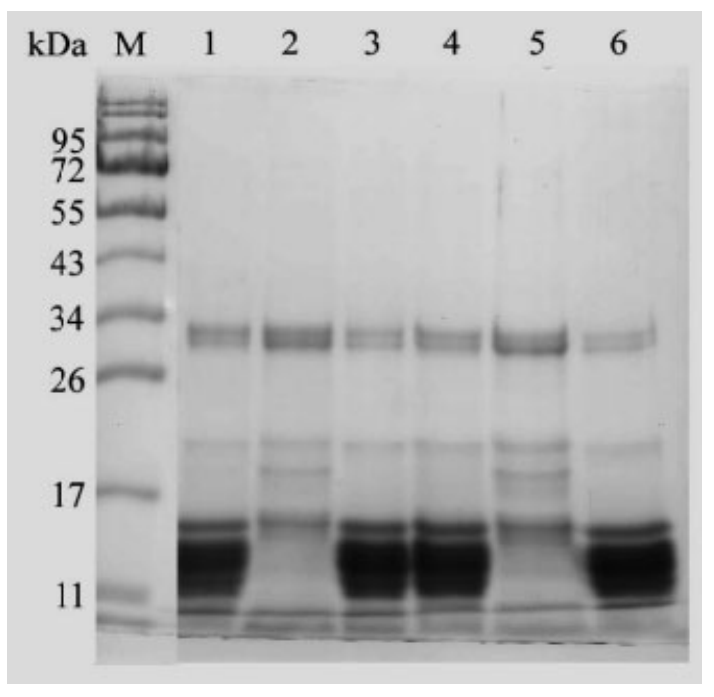

Figure 8. SDS-PAGE of ginger protease. 1, F; 2, FP1; 3, FP2; 4, A; 5, AP1; 6, AP2. Abbreviations as in Table 5.

the epoxide ring opens and inhibits the proteolytic activity. ${ }^{27}$ Leupeptin inhibits cysteine and serine proteases; iodoacetic acid has no specific residue to cysteine at the active site for cysteine protease and can react with other enzymes and small molecular thiol compounds. ${ }^{26}$ In this study, since P1 and P2 were inhibited by $\mathrm{E}-64$, leupeptin, and iodoacetic acid, this indicated that ginger proteases are cysteine proteases.

The relationship between ginger protease and milk-clotting activity is shown in Table 5 . The milk-clotting specific activity (MCSA) and total proteolytic specific activity (PSA) of the purified ginger proteases at $60{ }^{\circ} \mathrm{C}$ were tested. The experiment design used was the two-factor nested design in order to understand the differences in enzyme activity between the ginger proteases from acetone precipitate and the purified ginger proteases. The results in Table 5 show that the MCSA and PSA of P1 were higher than P2 $(P<0.05)$, but there was no significant difference between fresh ginger juice and juice treated with L-ascorbic acid addition. In this study, calf rennin was used as a standard clotting indicator; the ratio of the specific activity for the purified ginger protease enzyme versus that for the calf rennin enzyme at $60^{\circ} \mathrm{C}$ is shown in Table 6. The MCSA of P1 and P2 was found to be less than calf rennin, but the PSA of $\mathrm{P} 1$ was higher. Data for the MCSA/PSA ratio indicated that $\mathrm{P} 1$ and $\mathrm{P} 2$ both had a lower MCSA/PSA ratio than calf rennin, but the MCSA/PSA for P2 was approximately three times higher than $\mathrm{P} 1$. The milk-clotting activity/proteolytic activity of vegetable rennet was lower, resulting in cheese that was bitter during ripening time. ${ }^{9}$ For example, papain, ficin, and bromelain have a higher proteolytic activity and produce bitterness when used to make cheese. ${ }^{28}$ Protease with higher MCSA/PSA showed better curd formation ability and less bitterness development during cheese curd formation. Low MCSA/PSA may result in lower curd recovery and weak curd firmness. ${ }^{29}$ Owing to the high MCSA/PSA of P2, the P2 fraction of ginger protease can be a choice when making cheese products. In enzyme classification, the protease forms for ginger, papain, ficin, and bromelain are classified as cysteine proteases. ${ }^{30}$ The results of this study imply that ginger proteases can be a milk-clotting enzyme source that improves on the bitterness of milk products caused by papain, ficin and bromelain. The P1 fraction of ginger protease in this study had higher proteolytic activity and a higher recovery than the P2 
Table 3. Purification table of the ginger proteases

\begin{tabular}{|c|c|c|c|c|c|}
\hline Step & Total protein (mg) & Total activityc (unit) & $\begin{array}{l}\text { Specific activity } \\
\text { (unit } \mathrm{mg}^{-1} \text { protein) }\end{array}$ & $\begin{array}{l}\text { Purification } \\
\text { (factor) }\end{array}$ & Yield (\%) \\
\hline Fresh ginger juice $^{d}$ (37.2 mL) & 63.4 & 7.3 & 0.116 & 1.0 & 100.0 \\
\hline \multicolumn{6}{|l|}{ DEAE-FF fraction } \\
\hline $\mathrm{F}^{\mathrm{a}}$ & 39.3 & 5.0 & 0.126 & 1.1 & 67.4 \\
\hline F-P1 & 3.0 & 1.5 & 0.505 & 4.4 & 20.8 \\
\hline F-P2 & 19.9 & 1.8 & 0.088 & 0.8 & 23.9 \\
\hline Fresh ginger juice with $0.2 \%$ L-ascorbic acid ${ }^{d}(55.7 \mathrm{~mL})$ & 88.5 & 13.0 & 0.146 & 1.0 & 100.0 \\
\hline \multicolumn{6}{|l|}{ DEAE-FF fraction } \\
\hline$A^{b}$ & 47.7 & 6.7 & 0.140 & 1.0 & 51.5 \\
\hline A-P1 & 3.5 & 1.5 & 0.419 & 2.9 & 11.2 \\
\hline A-P2 & 26.3 & 2.1 & 0.079 & 0.5 & 16.0 \\
\hline
\end{tabular}

\begin{tabular}{|c|c|c|c|c|c|}
\hline \multirow[b]{3}{*}{ Inhibitor } & \multirow[b]{3}{*}{ Conc. $\left(\mu \mathrm{mol} \mathrm{L}^{-1}\right)$} & \multicolumn{4}{|c|}{ Proteases } \\
\hline & & $\mathrm{F}^{\mathrm{a}-\mathrm{P} 1}$ & F-P2 & $A^{b-P 1}$ & A-P2 \\
\hline & & \multicolumn{4}{|c|}{ Relative protease activity (\%) } \\
\hline Control & & $100.0 \pm 0.0$ & $100.0 \pm 0.0$ & $100.0 \pm 0.0$ & $100.0 \pm 0.0$ \\
\hline AEBSF $^{C}$ & 1000 & $98.1 b \pm 1.7$ & $97.7 b \pm 1.0$ & $96.4 \mathrm{a} \pm 0.8$ & $98.1 b \pm 0.5$ \\
\hline$E 64^{d}$ & 10 & $57.5 d \pm 3.4$ & $84.1 c \pm 2.7$ & $51.1 c \pm 15.0$ & $84.6 c \pm 0.9$ \\
\hline Leupeptin & 100 & $70.1 c \pm 0.9$ & $74.0 \mathrm{~d} \pm 1.1$ & $72.6 b \pm 2.4$ & $77.3 \mathrm{~d} \pm 1.7$ \\
\hline lodoacetic acid & 1000 & $28.7 e \pm 1.9$ & $67.1 \mathrm{e} \pm 1.1$ & $26.4 d \pm 8.8$ & $67.3 e \pm 0.6$ \\
\hline EDTA $^{\mathrm{e}}$ & 1000 & $104.9 \mathrm{a} \pm 2.7$ & $104.0 \mathrm{a} \pm 0.7$ & $100.6 a \pm 0.9$ & $103.0 \mathrm{a} \pm 0.5$ \\
\hline Pepstain A & 1.5 & $99.4 b \pm 0.8$ & $99.7 b \pm 1.1$ & $97.2 \mathrm{a} \pm 0.9$ & $98.1 b \pm 2.1$ \\
\hline \multicolumn{6}{|c|}{$\begin{array}{l}\text { a } F \text {, fresh ginger juice. } \\
\text { b A, fresh ginger juice with } 0.2 \% \text { L-ascorbic acid. } \\
{ }^{c} \text { AEBSF, 4-(2-aminoethyl)benzenesulfonyl fluoride hydrochloride. } \\
{ }^{d} \text { E-64, trans-epoxysuccinyl--l-leucylamido-(4-guanidino)butane. } \\
\text { e EDTA, ethylenediaminetetraacetic acid disodium dehydrate. } \\
\text { Means } \pm \text { SD with different letters within a column are significantly }\end{array}$} \\
\hline
\end{tabular}

fraction, but the lower MCSA/PSA of P1 weakens its application in milk products.

\section{Electrophoresis and zymography of ginger proteases}

Native PAGE revealed the native molecular mass in ginger proteases as shown in Fig. 5. The protein fractions of F-P2 and A-P2 were distributed into four groups: less than 14.2, 45 to 66, 66 , and $82 \mathrm{kDa}$. The molecular weights of the F-P1 and A-P1 fractions were 45 to 66 and $82 \mathrm{kDa}$; proteins with lower molecular weights were not present in the P1 fraction. The Native PAGE result indicated that L-ascorbic acid addition had no effect on the acetone precipitate ginger protease.

The individual casein substrate zymography results show protease activity for 62 and $82 \mathrm{kDa}$ (Fig. 6). When $\alpha$-casein was the substrate, all protease fractions showed protease activity for $62 \mathrm{kDa}$ (Fig. 6(a)), but the P2 fraction had an extra protease band located at $82 \mathrm{kDa}$. The results from $\beta$-casein substrate were the same as for $\alpha$-casein (Fig. 6(b)). The incubation time for the $\alpha$ - and $\beta$-casein test was $35 \mathrm{~min}$ at $37^{\circ} \mathrm{C}$, but the distinct band did not show up in the $\kappa$-casein test taking place at the same time (Fig. 6(c)). After doubling the protein concentration of ginger proteases loaded in the $\kappa$-casein gel for $60 \mathrm{~min}$, only the A fraction showed clear protease activity for 62 and 82 kDa (Fig. 7(a) and (b)). The results suggest that ginger protease has a lower affinity to $\kappa$-casein. All the protease fractions in this study could digest the three kinds of casein, but the protease with L-ascorbic acid addition showed an improved $\kappa$-casein digestibility. The molecular weights for F, A, F-P2, and A-P2 - estimated by SDS-PAGE - were measured to be $31,29,17$, and $13 \mathrm{kDa}$, respectively (Fig. 8). The molecular weights of F-P1 and A-P1 were 31, 29, 19, 17, and $13 \mathrm{kDa}$. Ichikawa et al. separated ginger proteases into GP I and GP II using DEAE-cellulose chromatography. The molecular weight of GP I and GP II was found to be $22.5 \mathrm{kDa}$ using Sephadex G-100 gel chromatography. ${ }^{3}$ Ohtsuki et al. separated ginger proteases into three fractions through isoelectric focusing with $\mathrm{p} /$ values of 4.5, 4.6, and 4.8. ${ }^{5}$ The TSK G20000SW XL gel chromatography results indicated that all three fractions were $29 \mathrm{kDa}$. Ginger proteases had protease activity for 62 and $82 \mathrm{kDa}$. The $62 \mathrm{kDa}$ molecule 
Table 5. Milk-clotting specific activity and total proteolytic specific activity of purified ginger proteases at $60^{\circ} \mathrm{C}$

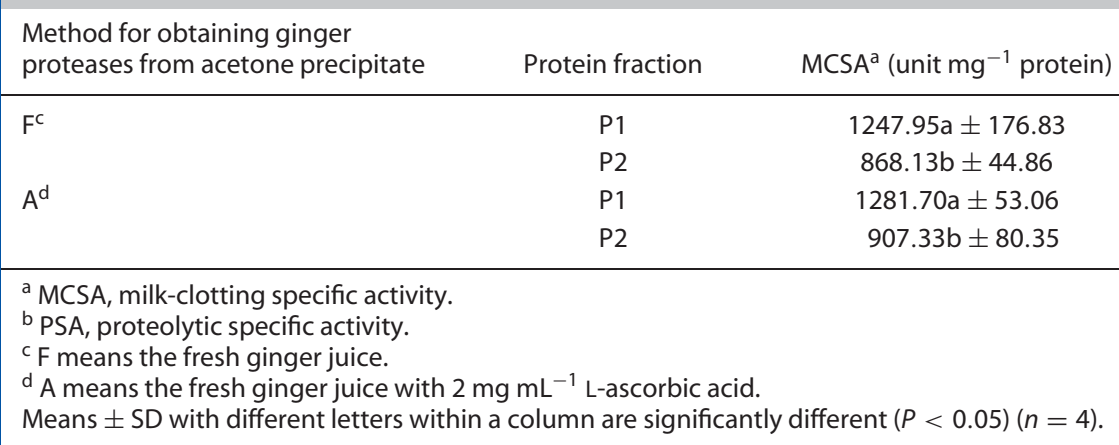

\begin{tabular}{|c|c|c|}
\hline Purified ginger protease $\mathrm{e}^{\mathrm{a}}$ & $\operatorname{MCSA} A^{b}(\%)$ & $\mathrm{PSA}^{\mathrm{C}}(\%)$ \\
\hline F-P1 & $0.28 \pm 0.04$ & $135.87 \pm 17.08$ \\
\hline F-P2 & $0.20 \pm 0.01$ & $30.69 \pm 6.16$ \\
\hline A-P1 & $0.29 \pm 0.01$ & $173.27 \pm 41.03$ \\
\hline A-P2 & $0.21 \pm 0.02$ & $29.35 \pm 5.78$ \\
\hline \multicolumn{3}{|c|}{$\begin{array}{l}\text { a } F \text {, fresh ginger juice; A, fresh ginger juice with } 2 \mathrm{mg} \mathrm{mL}^{-1} \mathrm{~L} \text {-ascorbic } \\
\text { acid. } \\
\mathrm{b} \text { MCSA, milk-clotting specific activity. Values are means } \pm \mathrm{SD}(n=4) \text {. } \\
\text { MCSA of calf rennin at } 60^{\circ} \mathrm{C} \text { was } 439982.40 \text { units. } \\
{ }^{C} \text { PSA, proteolytic specific activity. Values are means } \pm \mathrm{SD}(n=4) \text {. PSA } \\
\text { of calf rennin at } 60^{\circ} \mathrm{C} \text { was } 0.41 \text { units. }\end{array}$} \\
\hline
\end{tabular}

might be a dimer form, and the dimer has three combinations: two monomers of 29 and $31 \mathrm{kDa}$ or one monomer of 29 and $31 \mathrm{kDa}$. GP II was a monomer in solution, but GP II formed a loose tetramer in the crystal structure. Monomers I and II can each interact with monomers III and IV, but monomers III and IV cannot interact with each other directly. ${ }^{3}$ The molecule with $82 \mathrm{kDa}$ may be a dimer combined with a 13,17 , or $19 \mathrm{kDa}$ monomer to form a trimer.

\section{CONCLUSION}

In this study, ginger proteases were separated into two parts - P1 and P2 - using an anion-exchange column; the specific activity for MCA and PA of P1 was found to be higher than that of P2 $(P<0.05)$. Ascorbic acid addition significantly stabilized the MCA and PA of ginger protease stored at $4{ }^{\circ} \mathrm{C}$. The protease inhibition test indicated that $\mathrm{P} 1$ and $\mathrm{P} 2$ were cysteine proteases. Zymography results showed that the proteins of $\mathrm{P} 1$ had high proteolytic activity at $82 \mathrm{kDa}$, and P2 had high proteolytic activity at 62 and $82 \mathrm{kDa}$. Two protease fractions could digest $\alpha-, \beta$-, and $\kappa$-casein. The data in this study could be helpful in applying ginger proteases to making milk curd products and increasing the additional value of milk products.

\section{REFERENCES}

1 Choi KH and Laursen RA, Amino-acid sequence and glycan structures of cysteine proteases with proline specificity from ginger rhizome Zingiber officinale. Eur J Biochem 267:1516-1526 (2000).
3 Ichikawa Y, Sasa $\mathrm{H}$ and Michi K, Purification of ginger protease. J Jpn Soc Food Nutr 26:377-383 (1973).

4 Choi KH, Laursen RA and Allen KN, The 2.1 A structure of a cysteine protease with proline specificity from ginger rhizome, Zingiber officinale. Biochemistry 38:11624-11633 (1999).

5 Ohtsuki K, Taguchi K, Sato K and Kawabata M, Purification of ginger proteases by DEAE-Sepharose and isoelectric focusing. Biochim Biophys Acta 1243:181 - 184 (1995).

6 Adulyatham P and Owusu-Apenten R, Stabilization and partial purification of a protease from ginger rhizome (Zingiber officinale roscoe). J Food Sci 70:231-234 (2005).

7 Chen YY, Factors affecting protease activity of ginger and its application in milk clotting products. Masters thesis, Department of Animal Science, National Taiwan University (2004).

8 Grag SK and Johri BN, Rennet: current trends and future research. Food Rev int 10:313-355 (1994).

9 Sousa MJ, Ardo Y and McSweeney PLH, Advances in the study of proteolysis during cheese ripening. Int Dairy J 11:327-345 (2001).

10 Broome MC and Limsowtin GKY, Milk coagulants. Aust J Dairy Technol 53:188-190 (1998).

11 Demir Y, Gungor AA, Ozturk SBS and Demir N, The purification of protease from cowslip (Primula veris) and its use in food processing. J Food Process Preserv 31:559-570 (2007).

12 Demir Y, Gungor AA, Duran ED and Demir N, Cysteine protease (Capparin) from capsules of Caper (Capparis spinosa). Food Technol Biotechnol 46:286-291 (2008).

13 Bradford MM, A rapid and sensitive method for the quantitation of microgram quantities of protein utilizing the principle of proteindye binding. Anal Biochem 72:248-254 (1976).

14 Sousa MJ and Malcata FX, Proteolysis of ovine and caprine caseins in solution by enzymatic extracts from flowers of Cynara cardunculus. Enzyme Microb Technol 22:305-314 (1998).

15 Brock FM, Forsberg CW and Buchanan-Smith JG, Proteolytic activity of rumen microorganisms and effects of proteinase inhibitors. Appl Environ Microbiol 44:561 -569 (1982).

16 Wang HT and Hsu JT, Optimal protease production condition for Prevotella ruminicola 23 and characterization of its extracellular crude protease. Anaerobe 11:155-162 (2005).

17 García-Carreño FL, Dimes LE and Haard NF, Substrate-gel electrophoresis for composition and molecular weight of proteinases or proteinaceous proteinase inhibitors. Anal Biochem 214:65-69 (1993).

18 Shen ML, Experimental Designs. Jeou Chou Book Co., Taipei, Taiwan (2004).

19 Amiot MJ, Tacchini M, Aubert S and Nicolas J, Phenolic composition and browning susceptibility of various apple cultivars at maturity. J Food Sci 57:958-962 (1992).

20 Hunt MD, Eannetta NT, Yu H, Newman SM and Steffens JC, cDNA cloning and expression of potato polyphenol oxidase. Plant Mol Biol 21:59-68 (1993).

21 Mathew AG and Parpia HAB, Food browning as polyphenol reaction. Adv Food Res 19:75-145 (1971).

22 Matheis G and Whitaker JR, Modification of proteins by polyphenol oxidase and peroxidase and their products. J Food Biochem 8:137-162 (1983).

23 Mason HS, Comparative biochemistry of the phenolase complex. Adv Enzymol 16:105-184 (1995). 
24 Pierpoint WS, Formation and behaviour of $o$-quinones in some process of agricultural importance. Rep Rothamsted Exp St, 1970 Part 2, 199-218 (1971).

25 Pierpoint WS, o-Quinones formed in plant extracts: their reaction with bovine serum albumin. Biochem J 112:619-629 (1969).

26 Beynon RJ and Salvesen G, Proteolytic Enzymes: A Practical Approach. Information Press, Oxford (1989).

27 Yabe T and Kast A, The optimum $\mathrm{pH}$ of serum alkaline phosphatase after induced cholestasis in the male rat, mouse and rabbit. J Toxicol Sci 13:179-191 (1988).
28 Macedo IQ, Faro CJ and Pires EV, Caseinolytic specificity of cardosin, an aspartic protease from the cardoon Cynara cardunculus L: action on bovine $\alpha$ - and $\beta$-casein and comparison with chymosin. J Agric Food Chem 45:42-47 (1996).

29 Sardinas JL, Microbial rennets. Adv Appl Microbiol 15:39-73 (1972).

$30 \mathrm{Ott} \mathrm{HH}$ and Schirmeister T, Cysteine proteases and their inhibitors. Chem Rev 97:133-171 (1997). 